\title{
Assessment of Medical Waste Management in El Shifa and Al Aqsa Hospitals-Gaza Strip
}

\author{
Ahmed I. Abu Mhady1, Mohammed A. Awad1, Mohammed R. Al-Aghah ${ }^{2}$, Yasser Z. El-Nahhal2* \\ ${ }^{1}$ Department of Civil Engineering, Faculty of Engineering, The Islamic University Gaza, GGaza, Gaza Strip, Palestine \\ ${ }^{2}$ Department of Environmental and Earth Sciences, Faculty of Science, The Islamic University Gaza, Gaza”, Gaza Strip, Palestine \\ Email: *y_el_nahhal@hotmail.com
}

How to cite this paper: Abu Mhady, A.I., Awad, M.A., Al-Aghah, M.R. and El-Nahhal, Y.Z. (2019) Assessment of Medical Waste Management in El Shifa and Al Aqsa Hospitals-Gaza Strip. Health, 11, 1028-1042. https://doi.org/10.4236/health.2019.118081

Received: July 17, 2019

Accepted: August 13, 2019

Published: August 16, 2019

Copyright (c) 2019 by author(s) and Scientific Research Publishing Inc. This work is licensed under the Creative Commons Attribution International License (CC BY 4.0).

http://creativecommons.org/licenses/by/4.0/

(c) (i) Open Access

\begin{abstract}
Medical waste management is of great importance due to its infectious and hazardous nature and its management is not fully understood. This study examined the medical waste management practices in two large hospitals (El Shifa and Al Aqsa hospitals) in Gaza strip. The study used face to face questionnaire, workshops, interviews to managers and field observations for data collection. Results showed that both hospitals did not quantify medical wastes but medical wastes were separated in each department. Field observation indicated that medical waste separation into infectious medical waste and non-infectious medical waste was not conducted according to WHO (World Health Organization) standards or any specific standards. Medical wastes were transported from each department to waste container inside the hospital then moved to the storage area or municipal container. Medical waste employees $(n=51 ; 66.2 \%)$ revealed that medical wastes are stored temporarily in the hospital in a not suitable place in terms of ventilation, lighting and easy access. Furthermore, occupational safety among employees was not fully implemented, as large percentage of them $(n=48,94.1 \%)$ revealed that the used protective clothes during work were not fully effective. Furthermore, incineration was the main treatment of infectious medical waste whereas, non-infectious wastes were disposed in landfills. Additionally, both hospitals did not provide any training for employees regarding medical waste management. In conclusion, medical waste management is far below WHO standards in both hospitals. It is recommended to provide training courses to the employees to improve the quality of environmental health and reduce health hazards in the hospitals.
\end{abstract}

\section{Keywords}

Medical Waste, Hospital Waste, El Shifa Hospital, Al Aqsa Hospital, Health Hazards 


\section{Introduction}

Medical waste management is an important issue in the hospital to maintain the quality of health and reduce hazards to the employees, patients and visitors. Hospitals are crowded with employees, and visitors who may produce large fractions of waste that may increase the problem of medical waste management and pose threats to public health and environment [1].

Management of medical waste is a curtail issue to reduce hazards. Several efforts have been conducted to standardize management of wastes, this includes European classification of wastes [2], collection and disposal of waste [3]. So far, medical waste was not a priority in Palestine [4], and it was manually managed [5]. Nevertheless, medical waste management is poorly investigated in the region, deep research and quantitative data are marginally available. Medical waste management was conducted in Egypt [6], in Tehran [7], in Jordan [3], in Palestine [4] and other countries. The authors revealed different results probably due to different population in each country.

It has been shown that medical waste generation depends on many factors such as health care type, hospital specialization, available waste segregation options, number of hospital beds, and proportion of patients treated on a daily basis [8]. It has been found that medical waste in Greece was varied from 0.00124 $\mathrm{kg} / \mathrm{bed} /$ day (private psychiatric hospitals) to $0.718 \mathrm{~kg} / \mathrm{bed} /$ day (public university hospitals) [9], whereas in Bangladesh, the rate was $0.57 \mathrm{~kg} /$ patient/day [10]. The rate of medical waste in Palestine was between 0.33 and $0.84 \mathrm{~kg} /$ patient/day [11], but updated report [12] found $1.306 \mathrm{~kg} / \mathrm{bed} /$ day and an occupancy rate of $80 \%$. other reports [13] found $0.85 \mathrm{~kg} / \mathrm{bed} /$ day. Nevertheless, the generated waste in Iran included $51.6 \%$ of infectious waste, $47.2 \%$ general waste and $1.2 \%$ sharps [14].

Nevertheless, lack of awareness about medical waste management and financial analysis of all disposal coast may lead to a failure of management [15]. So far, the best medical waste management practice is to prevent and reduce the generation of waste [16] whereas medical waste treatment included: Autoclave, Microwave, Chemical Treatment: Incineration and land filling [17].

Medical waste management in Gaza Strip has not received sufficient consideration in health facilities. In fact, there may be inadequate management of medical waste in which they may be dumped with domestic waste. This may cause a major risk to the health of municipal workers. The authors designed this study to investigate medical waste management in two large hospitals in Gaza Strip in order to characterize, highlight, and suggest methods to improve the medical waste management in Gaza strip-Palestine.

\section{Methodology}

\subsection{Study Area}

Two hospitals in Gaza strip, El Shifa hospital and AL Aqsa hospital, were selected because they are located in different locations and serve many popula- 
tions. These hospitals include many medical departments.

\subsection{Sample Size}

About 246 employees (169 health and 77 cleaning worker) in both hospitals were randomly selected for data collection based on Slovin's Formula. The criteria for sample collection were actual representation without bias to any group with a low margin of error.

\subsection{Data Collection}

Data were collected according to the following steps.

\subsubsection{Field Visits}

Field visits to both hospitals were to oversee the daily practices of medical waste segregation, collection, storage, transportation and disposal. So far, the inspection of these activities was conducted by visual rating [18] [19] [20] [21] [22].

\subsubsection{Face to Face Interviews}

Face to face interviews were conducted stakeholders (Infectious Control Unit Officer, Primary Care and Preventive Medicine Officer) to collect in-depth details on medical waste management at both hospitals.

\subsection{Data Analysis}

The collected data were carefully checked and analyzed by SPSS program using the computer software SPSS version 22.0. Then statistical analysis included, average and standard deviation calculation. Percentages of values were also determined. P-value was calculated to check difference among hospitals.

\section{Results}

\subsection{Socio Demographic Factors}

Distribution of questionnaire respondents based on socio demographic factors is shown in Table 1.

It can be seen that male employees were the majority in both hospitals whereas female employees were the minority.

Furthermore, four age groups are working in medical waste management, the majority of them $(17.9 \%-30.9 \%)$ are in the thirties (30 - 39 year) and the minority $(6.1 \%-6.5 \%)$ of them were above fifties. Moreover, five education levels (illiterate, primary, secondary schools, diploma, first university degree and above) were found among medical waste management workers. Majority of employees $(14.6 \%-23.2 \%)$ have university degree whereas the minority of them were illiterate $(3.3 \%-6.5 \%)$. Daily working hours were in the range of $6-8$ $\mathrm{hr} /$ day. Additionally, there are differences in the above tested categories in both hospitals. This is probably due to differences in population size that each hospital services. 


\subsection{Composition of Medical Waste}

Types of clinical waste generated daily at the surveyed healthcare facilities are presented in Table 2.

Medical wastes collected from both hospitals are presented in Table 2. The waste included sharp, infectious wastes and pathological wastes. Based on employee replies, sharps wastes were the highest $(\mathrm{n}=140 ; 82.8 \%$ ), followed by infectious wastes $(\mathrm{n}=136 ; 80.5 \%)$ and pathological wastes $(\mathrm{n}=110 ; 65.1 \%)$. Moreover, the data indicated that medical waste in Shifa hospital is greater than Al-Aqsa hospital.

\subsection{Segregation and Containers}

Medical waste segregation practices at hospital are presented in Table 3.

Large fraction ( $n=73,73 \%)$ of medical staff at El Shifa hospital replied No to the question "On department medical waste separation" indicating no medical

Table 1. Distribution of respondents based on socio demographic factors.

\begin{tabular}{|c|c|c|c|}
\hline \multirow{2}{*}{\multicolumn{2}{|c|}{ Demographic parameters }} & \multicolumn{2}{|c|}{ Hospital name } \\
\hline & & Al Aqsa & El Shifa \\
\hline \multirow{3}{*}{ Gender } & Mal & $73(29.7 \%)$ & $103(41.9 \%)$ \\
\hline & Female & $24(9.8 \%)$ & $46(18.7 \%)$ \\
\hline & $\mathrm{G} 1=19-29$ years & $19(7.7 \%)$ & $30(12.2 \%)$ \\
\hline \multirow{3}{*}{ Age group } & $\mathrm{G} 2=30-39$ years & $44(17.9 \%)$ & $76(30.9 \%)$ \\
\hline & $\mathrm{G} 3=40-50$ years & $19(7.7 \%)$ & $27(11.0 \%)$ \\
\hline & $\mathrm{G} 4>50$ years & $15(6.1 \%)$ & $16(6.5 \%)$ \\
\hline \multirow{5}{*}{ Level of education } & Illiterate & $8(3.3 \%)$ & $16(6.5 \%)$ \\
\hline & Primary-Secondary School & $15(6.1 \%)$ & $27(11.0 \%)$ \\
\hline & Diploma & $20(8.1 \%)$ & $25(10.2 \%)$ \\
\hline & University Degree & $36(14.6 \%)$ & $57(23.2 \%)$ \\
\hline & Above & $18(7.3 \%)$ & $24(9.8 \%)$ \\
\hline
\end{tabular}

Table 2. Types of clinical waste generated daily at the surveyed healthcare facilities.

\begin{tabular}{ccc}
\hline \multirow{2}{*}{ Type of waste } & \multicolumn{2}{c}{ Hospital name } \\
\cline { 2 - 3 } General waste & Al Aqsa & El Shifa \\
Sharp & $69(100.0 \%)$ & $100(100.0 \%)$ \\
Infectious & $55(79.7 \%)$ & $85(85.0 \%)$ \\
Pathological & $44(63.8 \%)$ & $92(92.0 \%)$ \\
Pressurized containers & $35(50.7 \%)$ & $75(75.5 \%)$ \\
Pharmaceutical & $14(20.3 \%)$ & $22(22.0 \%)$ \\
Chemical & $18(26.1 \%)$ & $35(35.0 \%)$ \\
\end{tabular}


Table 3. Medical waste segregation practice at hospital for medical staff.

\begin{tabular}{|c|c|c|c|}
\hline \multirow{2}{*}{ Question } & \multirow{2}{*}{ Answer } & \multicolumn{2}{|c|}{ Hospital name } \\
\hline & & Al Aqsa & El Shifa \\
\hline \multirow{3}{*}{ On department medical waste separation } & Yes & $39(56.5 \%)$ & $14(14.0 \%)$ \\
\hline & No & $24(34.8 \%)$ & $73(73.0 \%)$ \\
\hline & I do not know & $6(8.7 \%)$ & $13(13.0 \%)$ \\
\hline \multirow{3}{*}{ Special mark of medical wastes container } & Yes & $37(53.6 \%)$ & $22(22.0 \%)$ \\
\hline & No & $26(37.7 \%)$ & $39(39.0 \%)$ \\
\hline & I do not know & $6(8.7 \%)$ & $39(39.0 \%)$ \\
\hline \multirow{3}{*}{ Availability of containers and bags } & Yes & $40(58.0 \%)$ & $57(57.0 \%)$ \\
\hline & No & $17(24.6 \%)$ & $23(23.0 \%)$ \\
\hline & I do not know & $12(17.4 \%)$ & $20(20.0 \%)$ \\
\hline \multirow{3}{*}{$\begin{array}{l}\text { Containers and bags available conform to } \\
\text { color code }\end{array}$} & Yes & $14(20.3 \%)$ & $14(14.0 \%)$ \\
\hline & No & $44(63.8 \%)$ & $66(66.0 \%)$ \\
\hline & I do not know & $11(15.9 \%)$ & $20(20.0 \%)$ \\
\hline \multirow{3}{*}{$\begin{array}{l}\text { Separation of general waste from medical } \\
\text { waste }\end{array}$} & Yes & $43(62.3 \%)$ & $15(15.0 \%)$ \\
\hline & No & $16(23.2 \%)$ & $77(77.0 \%)$ \\
\hline & I do not know & $10(14.5 \%)$ & $8(8.0 \%)$ \\
\hline \multirow{3}{*}{$\begin{array}{l}\text { Storage of medical waste according to the } \\
\text { color code }\end{array}$} & Yes & $36(52.2 \%)$ & $17(17.0 \%)$ \\
\hline & No & $17(24.6 \%)$ & $66(66.0 \%)$ \\
\hline & I do not know & $16(23.2 \%)$ & $17(17.0 \%)$ \\
\hline
\end{tabular}

separation occurred on department whereas the opposite is right at Al Aqsa hospital, the majority replied yes $(n=39.56 \%)$ to the same question. On the other hand, similar trends of responses were observed for the second question (Special mark of medical wastes container). Furthermore, majority of medical staff in both hospitals indicated positive answer to the question Availability of containers and bags in the hospitals, whereas low fraction responded with No to the same question mentioned above. On the other hand, majority of interviewed staff responded no to the question "Containers and bags available conform to color code". So far, similar answer was observed to the question "Separation of general waste from medical waste" and the following one "Storage of medical waste according to the color code". These answers indicated that regulations and separation standards of medical wastes are not applied in both hospitals.

Medical waste segregation practices at hospital for cleaning workers are presented in Table 4.

It can be seen that majority of workers $(76.9 \%-71.4 \%)$ in both hospitals replied Yes to the question "are there containers in all places that can produce medical waste". On the other hands minority of them indicated that they did not know. Furthermore, different replies were obtained regarding the question "are containers for medical wastes identified and distinguished from general". Moreover, 
Table 4. Medical waste segregation practice at hospital for cleaning worker.

\begin{tabular}{cccc}
\hline Hospital name & Reply & Al Aqsa & El Shifa \\
\hline \multirow{2}{*}{$\begin{array}{c}\text { Are there containers in all places that can } \\
\text { produce medical waste }\end{array}$} & Yes & $19(67.9 \%)$ & $35(71.4 \%)$ \\
& No & $4(14.3 \%)$ & $9(18.4 \%)$ \\
I do not know & $5(17.9 \%)$ & $5(10.2 \%)$ \\
$\begin{array}{c}\text { Are containers for medical wastes identified } \\
\text { and distinguished from general }\end{array}$ & Yes & $22(78.6 \%)$ & $15(30.6 \%)$ \\
& No & $6(21.4 \%)$ & $32(65.3 \%)$ \\
Sharp waste is collected separately in special & I do not know & $0(0.0 \%)$ & $2(4.1 \%)$ \\
containers & Yes & $24(85.7 \%)$ & $49(100.0 \%)$ \\
& No & $0(0.0 \%)$ & $0(0.0 \%)$ \\
& I do not know & $4(14.3 \%)$ & $0(0.0 \%)$ \\
\hline
\end{tabular}

majority of workers in both hospitals indicated that sharp waste were collected separately.

\subsection{Field Observations}

Field observations indicated the presence of red, yellow and black boxes for sharp waste, infectious waste and normal waste respectively. So far, Black boxes were dumped in the municipality containers inside the hospital whereas red and yellow boxes were disposed to the storage room for incineration The interview and site visits indicated that separation of infectious and noninfectious medical waste were not conducted according to WHO standards or any specific rules and standards.

\subsection{Pathological Waste}

Pathological wastes such as placenta, organs, tissues, blood, and other wastes were collected separately both hospitals and buried by the family of the patient.

\subsection{Pharmaceuticals Wastes}

Field visits to both hospitals indicated the presence of specialized committees that have responsibility of dumping expired medicine, unused or contaminated drugs and vaccines. The committee in each hospital decides the amount of pharmaceuticals that should be incinerated in the hospital.

\subsection{Medical Waste Collection Practices}

Table 5 presents information about waste collection practices.

It can be seen that cleaners in both hospitals stated that bags were filled above their storage capacity whereas other fraction gave different replies. On the other hands majority of cleaners indicated that bags are closely tied before transfer to the dumping site. Additionally, majority in both hospitals (75\% - 79\%) did not observe any leakage from the medical waste during transport to dumping site.

In contrast, majority of workers $(79.6 \%-89.3 \%)$ indicated that vessels used 
for the transport of a sharp waste are perforated. Moreover, majority or worker $(67.3 \%-78.6 \%)$ in both hospitals indicated that precautions are taken to prevent leakage of fluids from the bags.

\subsection{Medical Waste Transport Methods}

Table 6 shows the replies of cleaning staff to medical waste transport methods. Majority of the cleaners in both hospitals $(77.6 \%-85.7 \%)$ revealed that washing and distinction of waste containers occurred on daily basis on both hospitals whereas the minority provided negative answers. They also indicated that washing and disinfection of waste container are their own responsibilities. Additionally, majority of cleaners $(83.7 \%-85.7 \%)$ indicated that the number of transportation trolleys in the hospital is commensurate with the volume of waste whereas

Table 5. Collection practice at hospital for cleaning worker.

\begin{tabular}{cccc}
\hline Hospital name & Reply & Al Aqsa & El Shifa \\
\hline Bags filled above storage capacity & Yes & $11(39.3 \%)$ & $10(20.4 \%)$ \\
Bags filled and tied before transferred & No & $10(35.7 \%)$ & $32(65.3 \%)$ \\
& do not know & $7(25.0 \%)$ & $7(14.3 \%)$ \\
Leakage during transport & Yes & $19(67.9 \%)$ & $31(63.3 \%)$ \\
& No & $5(17.9 \%)$ & $9(18.4 \%)$ \\
do not know & $4(14.3 \%)$ & $9(18.4 \%)$ \\
$\begin{array}{c}\text { Precautions are taken to prevent leakage of fluids } \\
\text { from the bags (such as placing a bag inside a bag) }\end{array}$ & Yes & $7(25.0 \%)$ & $10(20.4 \%)$ \\
\hline
\end{tabular}

Table 6. Medical waste transportation at hospital for cleaning worker.

\begin{tabular}{|c|c|c|c|}
\hline \multirow{2}{*}{ Tested parameter } & \multirow{2}{*}{ Reply } & \multicolumn{2}{|c|}{ Hospital name } \\
\hline & & Al Aqsa & El Shifa \\
\hline \multirow{3}{*}{ Washing and disinfection of waste container } & Yes & $24(85.7 \%)$ & $38(77.6 \%)$ \\
\hline & No & $1(3.6 \%)$ & $2(4.1 \%)$ \\
\hline & do not know & $3(10.7 \%)$ & $9(18.4 \%)$ \\
\hline Responsibility waste container cleaning & Cleaners themselves & $24(100.0 \%)$ & $38(100.0 \%)$ \\
\hline \multirow{3}{*}{$\begin{array}{l}\text { The number of transportation trolleys in the } \\
\text { hospital is commensurate with the volume of } \\
\text { waste }\end{array}$} & Yes & $24(85.7 \%)$ & $41(83.7 \%)$ \\
\hline & No & $3(10.7 \%)$ & $4(8.2 \%)$ \\
\hline & I do not know & $1(3.6 \%)$ & $4(8.2 \%)$ \\
\hline $\begin{array}{l}\text { Medical waste are transported inside and } \\
\text { outside the hospital building using Trolley }\end{array}$ & Yes & $28(100.0 \%)$ & $49(100.0 \%)$ \\
\hline
\end{tabular}


minority $(8.2 \%$ - $10.7 \%)$ gave no reply. Furthermore, all workers (100\%) in both hospitals revealed that medical wastes are transported inside and outside hospitals using trolley.

\subsection{Medical Waste Storage, Suitability and Safety}

Medical Waste storage, suitability, capacity, safety and Accessibility at hospitals are presented at Table 7. It can be seen that majority of workers in both hospitals $(78.6 \%$ and $59.2 \%)$ revealed that medical wastes are temporally storage in side hospitals whereas minority did not know exactly. On the other hands minority of workers in both hospitals $(10.7 \%$ - 34.7\%) revealed that medical wastes are not temporarily stored in suitable place. So far, majority of workers revealed that storage place has enough rooms for medical wastes but neither safe nor associable one and have no marks indicating medical waste storage area. On the other hands, majority of workers $(90.9 \%$ - 93.1\%) indicated that medical wastes are stored in a suitable area inside the hospital with enough ventilation, lighting and easy access with sufficient capacity but no safety $(89.7 \%-100 \%)$ and no marks. Our results agree with previous reports [23] [24] [25] revealed similar results in hospitals in China and Istanbul. In contrast, different results were obtained in a hospital in Nablus in Palestine [5] which revealed that there is no special storage room for medical waste in the hospitals.

Nevertheless, medical waste collection, vehicle transport, storage are not comply with WHO standards for medical waste collection and transport. Moreover, the workers revealed that Ministry of Health has four incinerators for medical waste but they are not comply with WHO or EPA standards. Moreover,

Table 7. Medical Waste storage, suitability, capacity, safety and Accessibility at hospital.

\begin{tabular}{|c|c|c|c|}
\hline \multirow{2}{*}{ Tested parameter } & \multirow{2}{*}{ Reply } & \multicolumn{2}{|c|}{ Hospital name } \\
\hline & & Al Aqsa & El Shifa \\
\hline \multirow{3}{*}{$\begin{array}{l}\text { Temporarily storage of medical waste is inside } \\
\text { hospital }\end{array}$} & Yes & $22(78.6 \%)$ & $29(59.2 \%)$ \\
\hline & No & $3(10.7 \%)$ & $17(34.7 \%)$ \\
\hline & Do not know & $3(10.7 \%)$ & $3(6.1 \%)$ \\
\hline \multirow{2}{*}{$\begin{array}{l}\text { Suitability of storage area inside the hospital } \\
\text { (ventilation, lighting and easy access) }\end{array}$} & No & $20(90.9 \%)$ & $27(93.1 \%)$ \\
\hline & Do not know & $2(9.1 \%)$ & $2(6.9 \%)$ \\
\hline \multirow[t]{2}{*}{$\begin{array}{c}\text { Capacity of storage place inside hospital } \\
\text { (sufficient size) }\end{array}$} & No & $22(100.0 \%)$ & $29(100.0 \%)$ \\
\hline & Yes & $0(0.0 \%)$ & $3(10.3 \%)$ \\
\hline Safety of storage place & No & $22(100.0 \%)$ & $26(89.7 \%)$ \\
\hline \multirow{3}{*}{$\begin{array}{l}\text { Marks in the storage area inside the hospital } \\
\text { indicating the presence of medical waste }\end{array}$} & No & $19(86.4 \%)$ & $29(100.0 \%)$ \\
\hline & Do not know & $3(13.6 \%)$ & $0(0.0 \%)$ \\
\hline & Yes & $19(86.4 \%)$ & $3(10.3 \%)$ \\
\hline \multirow[t]{2}{*}{$\begin{array}{c}\text { Accessibility of storage area of medical waste in } \\
\text { the hospital }\end{array}$} & No & $0(0.0 \%)$ & $26(89.7 \%)$ \\
\hline & Do not know & $3(13.6 \%)$ & $0(0.0 \%)$ \\
\hline
\end{tabular}


medical waste officers revealed that $\mathrm{MOH}$ has two landfills in Gaza Strip. One is located in the north (Joher El Deek landfill) and received medical wastes from Al-Shifa hospital and the second one is located in south Gaza (Al Fokhari landfill) and received medical waste from Al-Aqsa Hospital.

\subsection{Occupational Health and Safety}

Occupational health and safety replies indicated that majority of workers (91\%) in both hospitals have no injury from dealing with medical wastes this probability due to vaccination before starting work. Nevertheless, workers revealed that they did not receive vaccinations periodically during work in the hospital. Additionally, majority of workers $(57.1 \%-67.3 \%)$ in both hospitals indicated that have knowledge about the medical waste management process whereas minority $(42.9 \%-32.7 \%)$ revealed opposite reply. On the other hand the majority of workers $(91.7 \%-92.9 \%)$ indicated that they received a training course in the field of medical waste management.

In another question, majority of workers $(60.7 \%-61.2 \%)$ indicated that they did not know the capacity of medical waste bags.

\subsection{Medical Waste Management Policies and Regulations}

Results of interview with infectious control stuff emphasized that there is no clear policy and plan in place for managing medical waste at Al Aqsa hospital. There is no definite policy or plan for purchasing the necessary equipment and for providing the facilities for the correct management of medical waste in the hospital. Infection control unit in the hospital has adopted a medical waste management guideline prepared by the infection control unit in Nasser_hospital but this is not strictly followed. There are still areas where medical wastes are not managed properly at the hospital. For instance, Infectious waste is not separated from normal in some sections. The hospital does not have a regular report about how medical waste management is practiced and the process of performing respective studies is also not reported.

\section{Discussion}

\subsection{Socio Demographic and Other Parameters}

The data in Table 1 clearly demonstrated variations in the socio demographical parameters of medical waste employees in both hospitals. these variations emerged from the fact that population has different culture and educational levels. Moreover, the hospitals are categorized from the largest hospitals and have different specialization and they serve different population beside the fact that population size and their socio economic parameters are quite different. These parameters are stand behind different replies of medical waste workers. Moreover, the differences in medical waste collected from both hospitals (Table 2) are probably emerged from the type of medical service provided by the hospital. For instance Shefa hospital did more surgical operation than any hospital in Gaza 
(Ministry of Health 2016 unpublished results), accordingly pathological wastes or infectious waste may be larger than any hospital. In the other hands Al-Aqsa hospital did many primary healthcare practices than other hospital in Gaza accordingly sharp waste generation may the highest at this hospital. Nevertheless, authors elsewhere [26] [27] [28] [29] [30] found similar results.

Furthermore medical waste segregation practice at both hospital (Table 3) stated different replies to the same question in both hospitals. The explanation of these results is that the medical stuff used to have new workers who did not yet received enough training consequently there replies are not in the same mode of replies but we have to consider them. Nevertheless, these differences in replies have also been reported in different countries [3] [6] [31] [32]. Additionally, medical waste segregation practice at hospitals (Table 4) has similar trend and explanation as above.

Moreover, Field observations indicated the presence of red, yellow and black boxes for sharp waste, infectious waste and normal waste respectively. This indicated good practice of medical waste management but this is still below the required level of quality [23], this is probably due to poor country.

Furthermore, Table 5 clearly indicated that waste bags were filled above their storage capacity and closely tied before transfer to the dumping site. The explanation of these results is medical waste bags are not easy to get them beside the fact that they are a little bit more expensive than regular bags. Accordingly the medical waste workers make use of each bag and filled it above the storage capacity. Furthermore, the volume of medical waste generated every day was above the volume capacity of the bags, accordingly the works made their efforts to remove the waste regardless that it was above capacity. Moreover, no leakage was observed from the bags regardless that medical waste was filled above capacity range. The explanation of this fact is that medical wastes were separated on site. And the wastes were gone to the right collection device. Additionally no leakage was observed from the bags probably because they are nearly dry wastes. Furthermore wet medical wastes such as those generated from surgical operation rooms or gynecology rooms were transferred directly to the incinerator in side hospital.

Nevertheless, the differences in replies of medical staff on medical waste transport methods (Table 6) are due to the fact that the medical waste workers belonged to different age group, educational levels and have different training course about medical waste management (Table 1). These differences in medical waste replies are quite normal since many authors revealed similar differences elsewhere. For instance Abor [33] from south Africa, Ferdowsi et al., [34] form Iran and Awodele et al. [35] from Nigeria reported similar observation.

Moreover, the discrepancy of replies in Table 7 emerged from the fact each hospital has his own area beside the fact that the total area of each hospital is quite narrow accordingly the medical waste is not suitably and safely stored. Our results agree with previous reports [23] [24] [25] that reported similar results in hospitals in China and Istanbul. In contrast, different results were obtained in a 
hospital in Nablus in Palestine [5] which revealed that there is no special storage room for medical waste in the hospitals. So far it appeared that medical waste were dumped in two landfills in Gaza Strip belonged to Ministry of health, one of them is located in the north part of Gaza (Joher El Deek landfill) and received medical wastes from Al-Shifa hospital and the second one is located in south Gaza (Al Fokhari landfill) and received medical waste from Al-Aqsa Hospital.

The high level of occupational health among medical waste staff may emerged from the fact that they have various levels of education (Table 1) and probably they received training course during work. Our findings are in accordance with authors from Turkey [25] from China [36] and elsewhere [3] who revealed the importance of training course in the field of medical waste management inside hospitals.

\subsection{Medical Waste Management Policies and Regulations}

The absence of clear policy and plan for managing medical waste at both hospitals emerged from the fact that both hospitals are under an ongoing contraction, and upgrading to meet the increasing demands of the populations in Gaza. Furthermore, the wars that Gaza Strip faced during the last five years makes the priority of development for human health not for medical waste management although both things are so critical for human life.

\subsection{Limitation of the Study}

1) Wars that Gaza faced during the last year disturbed the priority or work and planning.

2) Lack of necessary rules, regulations and instructions on the different aspects of collection and disposal of waste.

3) Mixture of hazardous wastes with domestic waste in the hospital sometimes.

4) Failure to quantify the waste generated unreliable records.

5) Lack of use of colored bags thereby limiting the bags to only two colors for all waste.

6) The absence of a committee responsible for monitoring medical waste management practices.

7) Lack of education and training on medical waste management.

8) The absence of a suitable place for temporary storage.

9) Lack of logistical support to improve hospital waste management.

\subsection{Environmental Relevance of Medical Waste}

The environmental relevance of this work emerged from the fact that medical waste contains pharmaceuticals that can be of harmful effects to many organisms in the ecosystem [37] [38] [39] a source of infection to new born [40] [41] and/or children [42]. Furthermore, part of medical waste can be remediated and be used for biogas production [43] [44]. 


\section{Conclusion}

Medical waste is generated from medical practice such as therapeutic procedures like dialysis, surgery, delivery, resection of gangrenous organs, autopsy, biopsy, Para-clinical exams, and injections among others. Segregation of medical wastes into infectious medical waste and non-infectious medical waste was not conducted according to definite rules and standards. The hospitals did not label infectious waste with Biohazard symbol. Separation of medical waste and general waste were not done at satisfactory methods. Wheeled trolleys are used for on-site transport of waste from the sites of production (different wards) to the temporary storage area or to the Municipal containers for final disposal. The working staff of medical waste in both hospitals did not use almost complete personal protective equipment. Al Shifa hospital has an incinerator for infectious waste disposal. Non-infectious waste was disposed using land disposal method in Joher El Deek and Al Fokhari landfills. Workers in medical waste were trained in potential hazards. The study showed that El Shifa and Al Aqsa hospitals don't have any policy for managing medical waste. Medical waste management was not adequately practiced according to WHO's recommended standards.

\section{Conflicts of Interest}

The authors declare no conflicts of interest regarding the publication of this paper.

\section{References}

[1] Pasupathi, P., Sindhu, S. and Ponnusha, B.S. (2011) Biomedical Waste Management for Health Care Industry: A Review. International Journal of Biological and Medical Research, 2, 472-486.

[2] Alvim-Ferraz, M.C.M. and Afonso, S.A.V. (2005) Incineration of Healthcare Wastes: Management of Atmospheric Emissions through Waste Segregation. Waste Management, 25, 638-648. https://doi.org/10.1016/j.wasman.2004.07.017

[3] Abdulla, F., Qdais, H.A. and Rabi, A. (2008) Site Investigation on Medical Waste Management Practices in Northern Jordan. Waste Management, 28, 450-458. https://doi.org/10.1016/j.wasman.2007.02.035

[4] Sarsour, A., Ayoub, A., Lubbad, I., Omran, A. and Shahrour, I. (2014) Assessment of Medical Waste Management within Selected Hospitals in Gaza Strip Palestine: A Pilot Study. International Journal of Scientific Research in Environmental Sciences, 2, 164. https://doi.org/10.12983/ijsres-2014-p0164-0173

[5] Al-Khatib, I.A. and Sato, C. (2009) Solid Health Care Waste Management Status at Health Care Centers in the West Bank-Palestinian Territory. Waste Management, 29, 2398-2403. https://doi.org/10.1016/j.wasman.2009.03.014

[6] Soliman, S.M. and Ahmed, A.I. (2007) Overview of Biomedical Waste Management in Selected Governorates in Egypt: A Pilot Study. Waste Management, 27, 1920-1923. https://doi.org/10.1016/j.wasman.2006.08.009

[7] Dehghani, M.H., Azam, K., Changani, F. and Fard, E.D. (2008) Assessment of Medical Waste Management in Educational Hospitals of Tehran University Medical Sciences. Journal of Environmental Health Science \& Engineering, 5, 131-136. 
[8] Debere, M.K., Gelaye, K.A., Alamdo, A.G. and Trifa, Z.M. (2013) Assessment of the Health Care Waste Generation Rates and Its Management System in Hospitals of Addis Ababa, Ethiopia, 2011. BMC Public Health, 13, 28. https://doi.org/10.1186/1471-2458-13-28

[9] Komilis, D., Fouki, A. and Papadopoulos, D. (2012) Hazardous Medical Waste Generation Rates of Different Categories of Health-Care Facilities. Waste Management, 32, 1434-1441. https://doi.org/10.1016/j.wasman.2012.02.015

[10] Alam, M.M., Sujauddin, M., Iqbal, G.M.A. and Huda, S.M.S. (2008) Report: Healthcare Waste Characterization in Chittagong Medical College Hospital, Bangladesh. Waste Management \& Research, 26, 291-296. https://doi.org/10.1177/0734242X07087661

[11] Al-Khatib, I.A., Al-Qaroot, Y.S. and Ali-Shtayeh, M.S. (2009) Management of Healthcare Waste in Circumstances of Limited Resources: A Case Study in the Hospitals of Nablus City, Palestine. Waste Management \& Research, 27, 305-312. https://doi.org/10.1177/0734242X08094124

[12] Environmental Quality Authority Palestinian Authority (2005) Master Plan for Healthcare Waste Management West Bank/Gaza Strip. http://www.undp.ps/en/forms/callforproposals/clarhcwmp.pdf

[13] Eleyan, D., Al-Khatib, I.A. and Garfield, J. (2013) System Dynamics Model for Hospital Waste Characterization and Generation in Developing Countries. Waste Management \& Research, 31, 986-995. https://doi.org/10.1177/0734242X13490981

[14] Bazrafshan, E. and Kord Mostafapoor, F. (2011) Survey of Medical Waste Characterization and Management in Iran: A Case Study of Sistan and Baluchestan Province. Waste Management \& Research, 29, 442-450. https://doi.org/10.1177/0734242X10374901

[15] Babanyara, Y.Y., Ibrahim, D.B., Garba, T., Bogoro, A.G. and Abubakar, M.Y. (2013) Poor Medical Waste Management (MWM) Practices and Its Risks to Human Health and the Environment: A Literature Review. Iranian Journal of Environmental Health, Science and Engineering, 11, 1-8.

[16] Hossain, M.S., Rahman, N.N.N.A., Balakrishnan, V., Puvanesuaran, V.R., Sarker, M.Z.I. and Kadir, M.O.A. (2013) Infectious Risk Assessment of Unsafe Handling Practices and Management of Clinical Solid Waste. International Journal of Environmental Research and Public Health, 10, 556-567. https://doi.org/10.3390/ijerph10020556

[17] Johannessen, L., Dijkman, M., Bartone, C., Hanrahan, D., Boyer, M.G. and Chandra, C. (2000) Healthcare Waste Management Guidance Note.

[18] El-Nahhal, Y., Nir, S., Polubesova, T., Margulies, L. and Rubin, B. (1998) Leaching, Phytotoxicity and Weed Control of New Formulations of Alachlor. Journal of Agricultural Food Chemistry, 46, 3305-3313. https://doi.org/10.1021/jf971062k

[19] El-Nahhal, Y., EL-dahdouh, N., Hamdona, N. and Alshanti, A. (2016) Toxicological Data of Some Antibiotics and Pesticides to Fish, Mosquitoes, Cyanobacterial Mats and to Plants. Data in Brief, 6, 871-880. https://doi.org/10.1016/j.dib.2016.01.051

[20] El-Nahhal, Y. and Hamdona, N. (2015) Phytotoxicity of Alachlor, Bromacil and Diuron as Single or Mixed Herbicides Applied to Wheat, Melon, and Molokhia. SpringerPlus, 4, 367. https://doi.org/10.1186/s40064-015-1148-7

[21] El-Nahhal, Y. and Hamdona, N. (2017) Adsorption, Leaching and Phytotoxicity of Some Herbicides as Single and Mixtures to Some Crops. Journal of the Association of Arab Universities for Basic and Applied Sciences, 22, 17-25. https://doi.org/10.1016/j.jaubas.2016.01.001 
[22] El-Nahhal, Y. (2018) Toxicity of Some Aquatic Pollutants to Fish. Environmental Monitoring and Assessment, 190, 449. https://doi.org/10.1007/s10661-018-6830-0

[23] WHO (2005) Medical Waste Management and Standards. Geneva.

[24] Zhang, Y., et al. (2009) Medical Waste Management in China: A Case Study of Nanjing. Waste Management, 29, 1376-1382. https://doi.org/10.1016/j.wasman.2008.10.023

[25] Birpınar, M.E., Bilgili, M.S. and Erdoğan, T. (2009) Medical Waste Management in Turkey: A Case Study of Istanbul. Waste Management, 29, 445-448. https://doi.org/10.1016/j.wasman.2008.03.015

[26] Mochungong, P.I. (2010) The Plight of Clinical Waste Pickers: Evidence from the Northwest Region of Cameroon. Journal of Occupational Health, 52, 142-145. https://doi.org/10.1539/joh.Q9004

[27] Gai, R., et al. (2010) Investigation of Health Care Waste Management in Binzhou District, China. Waste Management, 30, 246-250.

https://doi.org/10.1016/j.wasman.2008.08.023

[28] Silva, C.E., Hoppe, A.E., Ravanello, M.M. and Mello, N. (2005) Medical Wastes Management in the South of Brazil. Waste Management, 25, 600-605. https://doi.org/10.1016/j.wasman.2004.03.002

[29] Longe, E.O. and Williams, A. (2006) A Preliminary Study of Medical Waste Management in Lagos Metropolis, Nigeria. Journal of Environmental Health Science \& Engineering, 3, 133-139.

[30] Hassan, M.M., Ahmed, S.A., Rahman, K.A. and Biswas, T.K. (2008) Pattern of Medical Waste Management: Existing Scenario in Dhaka City, Bangladesh. BMC Public Health, 8, 36. https://doi.org/10.1186/1471-2458-8-36

[31] El-Salam, M.M.A. (2010) Hospital Waste Management in El-Beheira Governorate, Egypt. Journal of Environmental Management, 91, 618-629. https://doi.org/10.1016/j.jenvman.2009.08.012

[32] Askarian, M., Heidarpoor, P. and Assadian, O. (2010) A Total Quality Management Approach to Healthcare Waste Management in Namazi Hospital, Iran. Waste Management, 30, 2321-2326. https://doi.org/10.1016/j.wasman.2010.06.020

[33] Abor, P.A. (2007) Medical Waste Management at Tygerberg Hospital in the Western Cape, South Africa. Unpublished Doctoral Thesis, Cape Peninsula University of Technology, Cape Town.

[34] Ferdowsi, A., Ferdosi, M., Mehrani, Z. and Narenjkar, P. (2012) Certain Hospital Waste Management Practices in Isfahan, Iran. International Journal of Preventive Medicine, 3, S176.

[35] Awodele, O., Adewoye, A.A. and Oparah, A.C. (2016) Assessment of Medical Waste Management in Seven Hospitals in Lagos, Nigeria. BMC Public Health, 16, 269. https://doi.org/10.1186/s12889-016-2916-1

[36] Kumari, R., Srivastava, K., Wakhlu, A. and Singh, A. (2013) Establishing Biomedical Waste Management System in Medical University of India-A Successful Practical Approach. Clinical Epidemiology and Global Health, 1, 131-136. https://doi.org/10.1016/j.cegh.2012.11.004

[37] El-Nahhal, Y. and EL-dahdouh, N. (2015) Toxicity of Amoxicillin and Erythromycin to Fish and Mosquito. Ecotoxicology and Environmental Contamination, 10, 13-21. https://doi.org/10.5132/eec.2015.01.03

[38] EL-Nahhal, Y. and Alshanti, A. (2015) Toxicity of Single and Mixtures Antibiotics to Cyanobacteria. Environment and analytical Toxicology, 5, 1-8. 
[39] El-Nahhal, Y. and Hamms, Sh. (2017) Effects of Bromacil, Malathion and Thiabendazole on Cyanobacteria Mat Growth. International Journal of Applied Science Research and Review, 4, 1. https://doi.org/10.21767/2349-7238.100053

[40] El-Nahhal, Y. and Al-Shareef, A. (2018) Effective Biomarkers for Successful Management of Sepsis. Trends in Medicine, 18, 1-8. https://doi.org/10.15761/TiM.1000156

[41] El-Nahhal, Y.Z., Al-Shareef, A.T. and Alagha, M.R. (2019) Measurements of C-Reactive Protein for Successful Management and Follow-Up Treatment of Neonatal Sepsis and Nosocomial Infection. Health, 11, 721-732. https://doi.org/10.4236/health.2019.116060

[42] Safi, J.M., Yassin, M.M., El-Nahhal, Y.Z., Abed, Y.A., Safi, M.J. and Suleiman, H.D. (2019) Childhood Lead Poisoning in Gaza Strip, the Palestinian Authority. Journal of Trace Elements in Medicine and Biology, 54, 118-125. https://doi.org/10.1016/j.jtemb.2019.04.004

[43] Hammad, E.I., Al-Agha, M.R. and El-Nahhal, Y. (2019) Influence of Biogas Production on Bioremediation of Animal Manures. American Journal of Analytical Chemistry, 10, 1-8. https://doi.org/10.4236/ajac.2019.101001

[44] Hammad, E.I., Al-Agha, M.R. and El-Nahhal, Y. (2018) Enhancing Biogas Production: Influence of Mixing Cow and Chicken Manures. Energy and Power Engineering, 10, 383-397. https://doi.org/10.4236/epe.2018.108024 